\title{
Oxidative Status and Antioxidative Response to Fusarium Attack and Different Nitrogen Levels in Winter Wheat Varieties
}

\author{
Magdalena Matić ${ }^{1}$ (D), Rosemary Vuković ${ }^{2, *}$, Karolina Vrandečić ${ }^{1,3, *}$, Ivna Štolfa Čamagajevac ${ }^{2}$, Jasenka Ćosić ${ }^{1} \mathbb{D}$, \\ Ana Vuković ${ }^{2}$, Kristina Sabljić ${ }^{2}$, Nikolina Sabo ${ }^{2}$, Krešimir Dvojković 4 (D) and Dario Novoselovićc ${ }^{3,4}$ (D) \\ 1 Faculty of Agrobiotechnical Sciences, Josip Juraj Strossmayer University of Osijek, Vladimira Preloga 1, \\ 31000 Osijek, Croatia; maticm@fazos.hr (M.M.); jcosic@fazos.hr (J.Ć.) \\ 2 Department of Biology, Josip Juraj Strossmayer University of Osijek, Cara Hadrijana 8/A, 31000 Osijek, \\ Croatia; ivna@biologija.unios.hr (I.Š.Č.); ana.vukovic@biologija.unios.hr (A.V.); \\ kristina.sabljic@biologija.unios.hr (K.S.); nikolina.sabo@biologija.unios.hr (N.S.) \\ 3 Centre of Excellence for Biodiversity and Molecular Plant Breeding (CoE CroP-BioDiv), 10000 Zagreb, Croatia; \\ darion@poljinos.hr \\ 4 Department for Cereal Breeding and Genetics, Agricultural Institute Osijek, Južno Predgrađe 17, 31000 Osijek \\ Croatia; kresimir.dvojkovic@poljinos.hr \\ * Correspondence: rosemary@biologija.unios.hr (R.V.); kvrandecic@fazos.hr (K.V.)
}

\section{check for} updates

Citation: Matić, M.; Vuković, R.; Vrandečić, K.; Štolfa Čamagajevac, I.; Ćosić, J.; Vuković, A.; Sabljić, K.; Sabo, N.; Dvojković, K.; Novoselović, D. Oxidative Status and Antioxidative Response to Fusarium Attack and Different Nitrogen Levels in Winter Wheat Varieties. Plants 2021, 10, 611. https://doi.org/10.3390/plants 10040611

Academic Editor: Peter Schroeder

Received: 25 February 2021

Accepted: 21 March 2021

Published: 24 March 2021

Publisher's Note: MDPI stays neutral with regard to jurisdictional claims in published maps and institutional affiliations.

Copyright: (c) 2021 by the authors. Licensee MDPI, Basel, Switzerland. This article is an open access article distributed under the terms and conditions of the Creative Commons Attribution (CC BY) license (https:/ / creativecommons.org/licenses/by/ $4.0 /)$.

\begin{abstract}
Abiotic and biotic stresses, such as mineral nutrition deficiency (especially nitrogen) and Fusarium attack, pose a global threat with devastating impact on wheat yield and quality losses worldwide. This preliminary study aimed to determine the effect of Fusarium inoculation and two different nitrogen levels on oxidative status and antioxidative response in nine wheat varieties. Level of lipid peroxidation, activities of antioxidant enzymes (catalase, ascorbate peroxidase, glutathione reductase), phenolics, and chloroplast pigments content were measured. In general, wheat variety, nitrogen, and Fusarium treatment had an impact on all tested parameters. The most significant effect had a low nitrogen level itself, which mostly decreased activities of all antioxidant enzymes and reduced the chloroplast pigment content. At low nitrogen level, Fusarium treatment increased activities of some antioxidative enzymes, while in a condition of high nitrogen levels, antioxidative enzyme activities were mostly decreased due to Fusarium treatment. The obtained results provided a better understanding on wheat defense mechanisms against F. culmorum, under different nitrogen treatments and can serve as an additional tool in assessing wheat tolerance to various environmental stress conditions.
\end{abstract}

Keywords: Triticum aestivum; Fusarium; nitrogen; oxidative stress; antioxidant system

\section{Introduction}

Wheat (Triticum aestivum L.) is one of the most important cereal crops worldwide. In field conditions, wheat is confronted with both abiotic and biotic stresses that have a great impact on its growth and productivity [1]. Nitrogen $(\mathrm{N})$ is one of the major nutritional elements in wheat production, and it is necessary to achieve high yields and grain quality [2]. Wheat quickly perceives and responds to nitrogen deficiency via a large number of physiological and metabolic events, such as the changes in fatty acid composition, reduction in chlorophyll content, and occurrence of oxidative stress [3]. During cultivation, wheat is often exposed to Fusarium head blight (FHB), an economically devastating disease that may exert an adverse impact on the wheat yield and quality [4]. Global yield losses due to individual pathogen and pests are estimated at $21.5 \%$ for wheat, whereas yield losses due to FHB ranked second after leaf rust [5]. FHB is caused by species of fungi in the genus Fusarium, of which Fusarium graminearum Schwabe (Gibberella zeae Schwein. Petch.) and Fusarium culmorum (Wm. G. Sm.) Sacc. are the most common and most virulent in Croatia [6]. 
It is now well established that all abiotic and biotic stresses induce or involved oxidative stress to some degree, and the ability of plants to control oxidant levels is highly correlated with stress tolerance [7]. Oxidative stress is a complex chemical and physiological phenomenon that arises due to excessive production and accumulation of reactive oxygen species (ROS) and reactive nitrogen species (RNS) [8,9]. The balance between production and elimination of ROS and RNS is critical to maintaining cellular redox homeostasis. Excessive production of ROS and RNS can induce a nitro-oxidative stress in plant cells, which causes lipid peroxidation, damages proteins and nucleic acids, inhibits antioxidant enzyme activities and activates the programmed cell death pathway $[8,10]$. In order to overcome the high levels of ROS and RNS, plants developed an efficient antioxidant defense system constitutes both enzymatic and nonenzymatic components. Enzymatic components that are involved in the detoxification of reactive species include superoxide dismutase (SOD), catalase (CAT), ascorbate peroxidase (APX), and glutathione reductase (GR), while the non-enzymatic components include small molecules such phenolics (PHE), flavonoids, pigments, ascorbate, and glutathione [8,11].

Plant tolerance to different stress factors can be achieved by plant breeding or cultural practices that reduce levels of stress, which is in turn accomplished by the understanding of the plant's response to its stressors and how they affect individual plants and plant processes [12]. This study aimed to determine the effect of two different nitrogen levels and Fusarium inoculation on the biomarkers of oxidative and antioxidative status (lipid peroxidation, PHE, and activities of CAT, APX, and GR) measured in the spikes of nine wheat varieties. Although numerous studies have analyzed wheat's physiological response to Fusarium stress itself [13-15], this preliminary study will give insight into wheat's physiological response to combined nitrogen and Fusarium stress conditions.

\section{Results}

Three-way ANOVA showed significant differences in visual FHB scoring for all the main factors (Table 1). The visual scoring for FHB was affected mainly by Fusarium treatment and wheat variety $(p \leq 0.001)$ and to a lesser extent by nitrogen treatment $(p \leq 0.05)$. Non-inoculated wheat varieties did not show any FHB symptoms; thus statistical differences between inoculated and non-inoculated plants are not shown. Differences in symptoms of inoculated wheat varieties at low and high nitrogen levels for each variety separately are shown (Table 2). In Ficko, Galloper, and Felix varieties high nitrogen level caused an increase in visual symptoms. Contrarily, in variety U-1 high nitrogen level caused a decrease in visual symptoms.

Table 1. Three-way ANOVA for visual scoring and five different biochemical parameters under different nitrogen and Fusarium treatments in spikes of nine winter wheat varieties.

\begin{tabular}{cccccccc}
\hline & \multicolumn{7}{c}{ MS } \\
\hline Source of Variation & df & VS $^{2}$ & TBARS & PHE & CAT & APX & GR \\
\hline VARIETY (V) & 8 & $0.08^{* * *}$ & $59.92^{* * *}$ & $108.02^{* * *}$ & $1700.63^{* * *}$ & $1.295^{* * *}$ & $719.05^{* * *}$ \\
N LEVEL (N) & 1 & $0.04^{* * *}$ & $43.73^{* *}$ & $20.51 \mathrm{~ns}$ & $1215.25^{* *}$ & $4.227^{* * *}$ & $180.06 \mathrm{~ns}$ \\
FUSARIUM (F) & 1 & $23.02^{* * *}$ & $11.62 \mathrm{~ns}$ & $190.55^{* * *}$ & $669.20^{*}$ & $0.001 \mathrm{~ns}$ & $733.05^{*}$ \\
V $\times \mathrm{N}$ & 8 & $0.14^{* * *}$ & $17.14^{* * *}$ & $38.75^{*}$ & $163.39 \mathrm{~ns}$ & $0.571^{* * *}$ & $176.72 \mathrm{~ns}$ \\
V $\times \mathrm{F}$ & 8 & $0.08^{* * *}$ & $6.78 \mathrm{~ns}$ & $25.96 \mathrm{~ns}$ & $801.97^{* * *}$ & $0.307^{* * *}$ & $299.44^{* *}$ \\
$\mathrm{~N} \times \mathrm{F}$ & 1 & $0.04^{*}$ & $2.31 \mathrm{~ns}$ & $153.85^{* *}$ & $1769.33^{* * *}$ & $0.338^{*}$ & $808.47^{*}$ \\
$\mathrm{~V} \times \mathrm{N} \times \mathrm{F}$ & 8 & $0.14^{* * *}$ & $7.16 \mathrm{~ns}$ & $27.53 \mathrm{~ns}$ & $579.37^{* * *}$ & $0.439^{* * *}$ & $321.27 \mathrm{~ns}$ \\
\hline
\end{tabular}

ns-not significant, ${ }^{*}, * *$ and ${ }^{* * *}$ - significant at the level of probability $p \leq 0.05,0.01$, and 0.001, respectively. Df, degrees of freedom; MS, mean sum of squares; VS, visual scoring (in percentage inoculated spikes); TBARS, thiobarbituric acid reactive substances; PHE, phenolics; CAT, catalase; APX, ascorbate peroxidase; GR, glutathione reductase. ${ }^{2}$ A log transformation of the visual scores was used to normalize the data. 
Table 2. Visual scores for Fusarium head blight (FHB) of nine inoculated winter wheat varieties under two different nitrogen levels.

\begin{tabular}{|c|c|c|c|c|c|c|c|c|c|}
\hline \multirow[b]{2}{*}{ N level } & \multicolumn{9}{|c|}{ Visual Scores (in Percentage Inoculated Spikes) } \\
\hline & Ficko & U-1 & Galloper & BC Mandica & BC Opsesija & Ingenio & Isengrain & Felix & Bezostaya-1 \\
\hline LN & $6.67 \pm 1.53 b$ & $8.00 \pm 1.00 \mathrm{a}$ & $3.33 \pm 1.53 b$ & $9.00 \pm 5.29 a$ & $20.00 \pm 10.00 a$ & $10.33 \pm 4.51 \mathrm{a}$ & $10.00 \pm 0.00 \mathrm{a}$ & $8.33 \pm 2.89 b$ & $5.00 \pm 0.00 a$ \\
\hline $\mathrm{HN}$ & $25.00 \pm 5.00 \mathrm{a}$ & $3.33 \pm 0.58 \mathrm{~b}$ & $10.00 \pm 0.00 \mathrm{a}$ & $7.00 \pm 2.65 \mathrm{a}$ & $4.33 \pm 0.58 \mathrm{a}$ & $10.33 \pm 4.51 \mathrm{a}$ & $8.33 \pm 2.89 \mathrm{a}$ & $32.67 \pm 2.52 \mathrm{a}$ & $8.00 \pm 2.00 \mathrm{a}$ \\
\hline
\end{tabular}

Values are means of three replicates \pm standard deviation (SD). Different letters indicate significant differences according to Fisher's LSD test $(p \leq 0.05)$ among different nitrogen treatments in each variety separately. LN-low nitrogen; HN-high nitrogen.

Three-way ANOVA revealed a significant variety, nitrogen and Fusarium treatment effects for tested biochemical parameters (Table 1$)$. Wheat variety significantly affected all tested biochemical parameters $(p \leq 0.001)$, while nitrogen treatment significantly affected thiobarbituric acid reactive substances (TBARS) content, CAT and APX activity. Fusarium treatment mostly affected PHE content $(p \leq 0.001)$, and to a lesser extent, CAT and GR activity $(p \leq 0.05)$. Variety by nitrogen treatment interaction was significant for TBARS, PHE accumulation, and APX activity. Three-factor interaction between the variety, nitrogen, and Fusarium treatment was significant only for CAT and APX activity.

TBARS content was significantly influenced by the wheat variety and nitrogen treatment (Table 1). In the Ficko variety at low nitrogen level, Fusarium treatment caused a decrease in TBARS content, while in the Galloper variety, the content of TBARS was increased (Figure 1a). In conditions of high nitrogen level, Fusarium treatment did not cause any significant changes in TBARS content. In most non-inoculated varieties, low nitrogen level tended to increase TBARS content, although a significant increase was only found in the Ficko and Bezostaya-1 varieties.
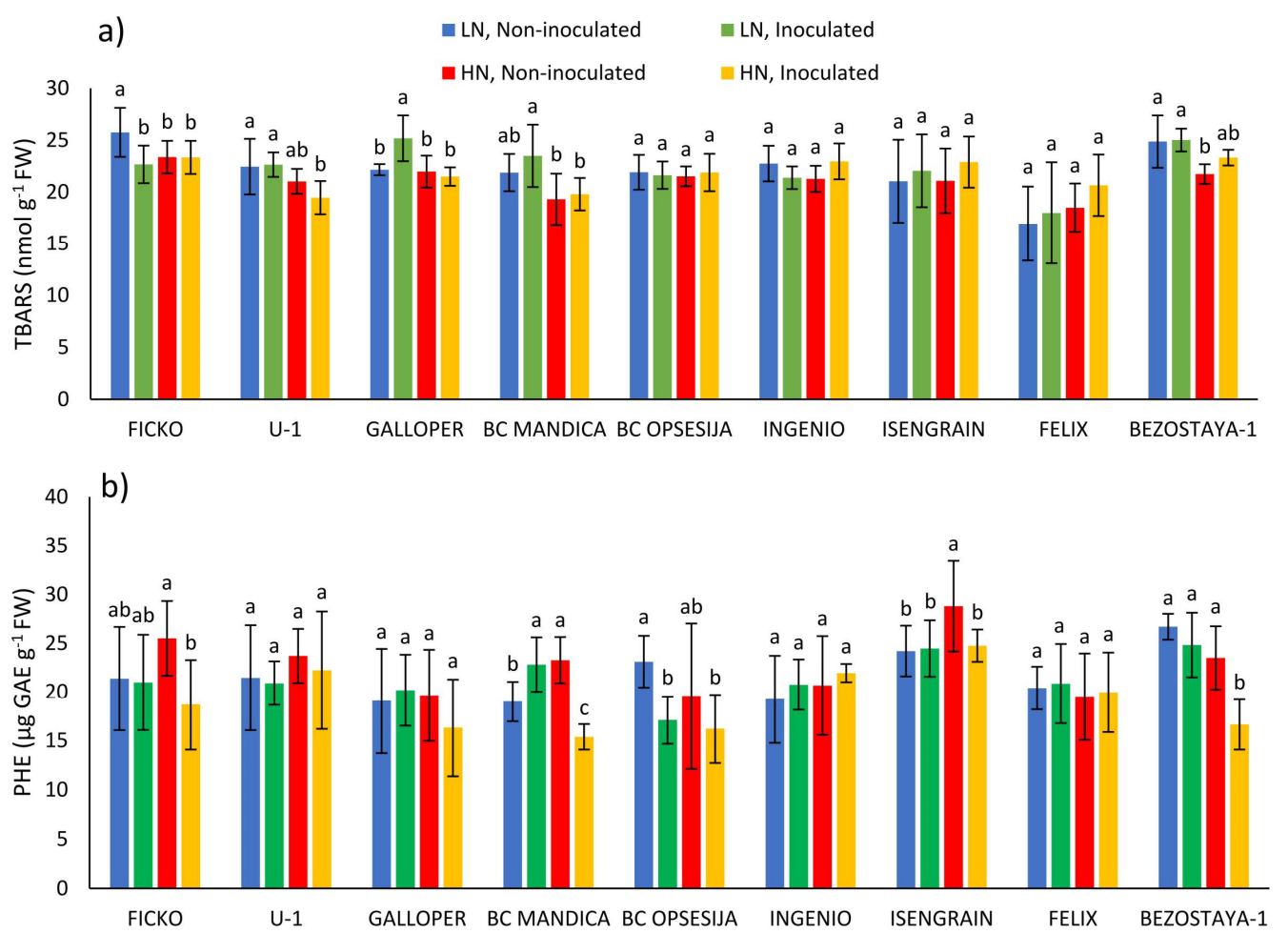

Figure 1. TBARS content (a) and soluble phenolic (PHE) content (b) in spikes of nine wheat varieties under different nitrogen (LN-low nitrogen; $\mathrm{HN}$-high nitrogen) and Fusarium (non-inoculated and inoculated) treatments. Values are means of six replicates \pm standard deviation (SD). Different letters above the bars indicate significant differences according to Fisher's LSD test $(p \leq 0.05)$ among different treatments in each variety separately. 
The soluble phenolic content was most significantly affected by Fusarium treatment and wheat variety (Table 1). Fusarium treatment caused an increase in soluble phenolic content in BC Mandica variety at low nitrogen level, while in the BC Opsesija variety this content was decreased (Figure 1b). In conditions of high nitrogen level, Fusarium treatment caused a decrease in phenolic content in the Ficko, BC Mandica, Isengrain and, Bezostaya-1 varieties. In most non-inoculated varieties, low nitrogen level decreased phenolic content, although a significant decrease was only found in the BC Mandica and Isengrain varieties.

The CAT activity was significantly influenced by all three main factors, wheat variety $(p \leq 0.001)$, nitrogen $(p \leq 0.01)$, and Fusarium treatment $(p \leq 0.05$; Table 1$)$. On average, a low nitrogen level caused a decrease of $5.46 \%$ in CAT activity compared to a high nitrogen level. Observing the changes in CAT activity in each variety separately, in the U-1, BC Mandica, Isengrain, Felix, and Bezostaya-1 varieties, at low nitrogen level, Fusarium treatment caused an increase in CAT activity (Figure 2a). In conditions of high nitrogen level, Fusarium treatment caused a decrease in CAT activity in the Isengrain variety. In most non-inoculated varieties, low nitrogen level decreased CAT activity, although a significant decrease was found in the BC Mandica and Isengrain varieties.

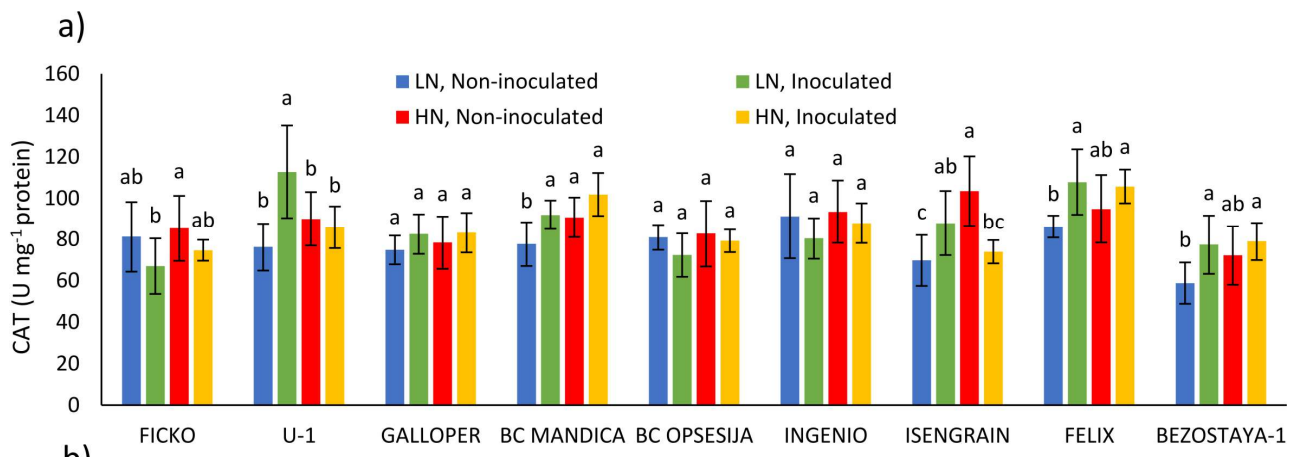

b)

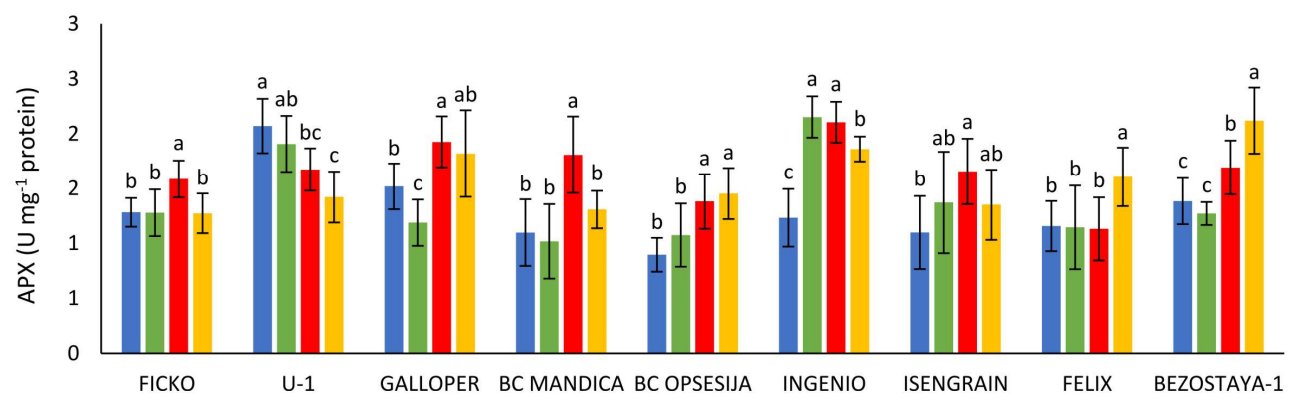

c)

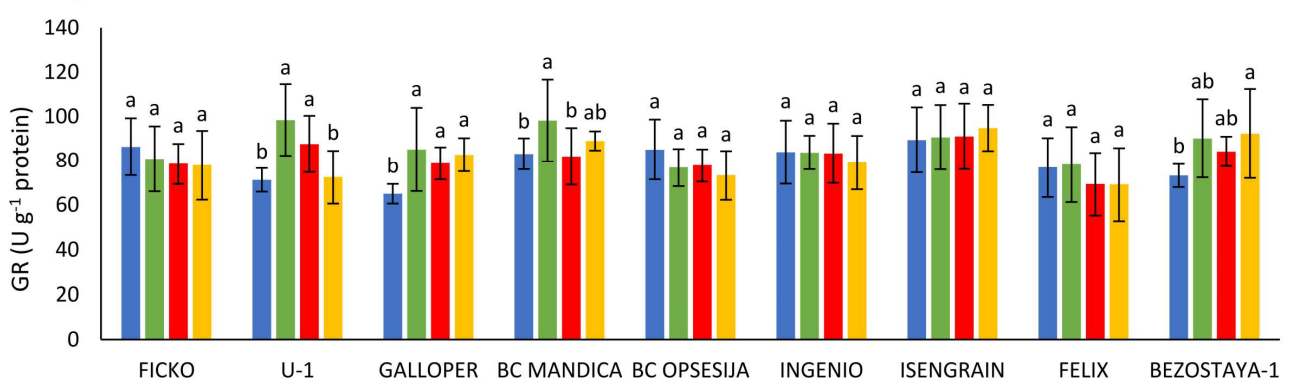

Figure 2. Antioxidant enzyme activity: catalase (CAT; (a)), ascorbate peroxidase (APX; (b)), and glutathione reductase (GR; (c)) in spikes of nine wheat varieties under different nitrogen (LN-low nitrogen; HN-high nitrogen) and Fusarium (non-inoculated and inoculated) treatments. Values are means of six replicates \pm standard deviation (SD). Different letters above the bars indicate significant differences according to Fisher's LSD test $(p \leq 0.05)$ among different treatments in each variety separately. 
The APX activity was most significantly influenced by nitrogen treatment and wheat variety (Table 1). On average, a low nitrogen level caused a decrease of $17.26 \%$ in APX activity compared to a high nitrogen level. Observing the changes in APX activity in each variety separately, in the Galloper variety at low nitrogen level, Fusarium treatment caused a decrease in APX activity, while in the Ingenio APX activity was increased (Figure 2b). In conditions of high nitrogen level, Fusarium treatment caused a decrease in APX activity in Ficko, BC Mandica, and Ingenio varieties, while in Felix and Bezostaya-1 varieties, APX activity was increased. In most non-inoculated varieties (Ficko, Galloper, BC Mandica, BC Opsesija, Ingenio, Isengrain, and Bezostaya-1), low nitrogen level significantly decreased APX activity, compared to high nitrogen level.

The GR activity was most significantly influenced by wheat variety $(p \leq 0.001)$, and to a lesser extent, Fusarium treatment ( $p \leq 0.05$; Table 1). In U-1, Galloper and BC Mandica varieties, at low nitrogen, Fusarium treatment caused an increase in GR activity, while, at high nitrogen conditions, GR activity was decreased only in U-1 variety (Figure 2c). Compared to high nitrogen level, low nitrogen level significantly decreased GR activity in non-inoculated U-1 and Galloper varieties.

Three-way ANOVA revealed a wide variety, nitrogen and Fusarium treatment effects for tested chloroplast pigments (Table 3). Wheat variety and nitrogen treatment significantly affected all tested chloroplast pigments in wheat spikes. Fusarium treatment significantly affected almost all tested chloroplast pigments, except the $\mathrm{Chl}$ a/Chl b ratio.

Table 3. Three-way ANOVA for different chloroplast pigments under different nitrogen and Fusarium treatment in spikes of nine winter wheat varieties.

\begin{tabular}{|c|c|c|c|c|c|c|}
\hline & & & & MS & & \\
\hline Source of Variation & df & Chl a & Chl b & Chl $a+b$ & Car & Chl a/Chl b \\
\hline VARIETY (V) & 8 & $0.0128^{* * *}$ & $0.0015^{* * *}$ & $0.0228^{* * *}$ & $0.0008^{* * *}$ & $0.0745 * *$ \\
\hline N LEVEL (N) & 1 & $0.0363^{* * *}$ & $0.0058^{* * *}$ & $0.0712^{* * *}$ & $0.0019^{* * *}$ & $0.1192 *$ \\
\hline FUSARIUM (F) & 1 & $0.0204^{* * *}$ & $0.0033^{* * *}$ & $0.0402^{* * *}$ & $0.0014^{* * *}$ & $0.0592 \mathrm{~ns}$ \\
\hline $\mathrm{V} \times \mathrm{N}$ & 8 & $0.0011 \mathrm{~ns}$ & $0.0002 \mathrm{~ns}$ & $0.0022 \mathrm{~ns}$ & $0.0001 \mathrm{~ns}$ & $0.0217 \mathrm{~ns}$ \\
\hline $\mathrm{V} \times \mathrm{F}$ & 8 & $0.0025 *$ & $0.0004 *$ & $0.0050 *$ & $0.0002 \mathrm{~ns}$ & $0.0258 \mathrm{~ns}$ \\
\hline $\mathrm{N} \times \mathrm{F}$ & 1 & $0.0028 \mathrm{~ns}$ & $0.0003 \mathrm{~ns}$ & $0.0049 \mathrm{~ns}$ & $0.0002 \mathrm{~ns}$ & $0.0059 \mathrm{~ns}$ \\
\hline $\mathrm{V} \times \mathrm{N} \times \mathrm{F}$ & 8 & $0.0049^{* * *}$ & $0.0008^{* * *}$ & $0.0097^{* * *}$ & $0.0003^{* * *}$ & $0.0229 \mathrm{~ns}$ \\
\hline
\end{tabular}

The strongest effect on chlorophyll a (Chl a), chlorophyll b (Chl b), total chlorophyll $(\mathrm{Chl} \mathrm{a}+\mathrm{b})$, carotenoids (Car) content, and chlorophyll a/b ratio in wheat spikes was found in the nitrogen treatment (Table 3). On average, a low nitrogen level decreased $\mathrm{Chl} \mathrm{a,} \mathrm{Chl}$ $\mathrm{b}, \mathrm{Chl} \mathrm{a}+\mathrm{b}$, and Car content in wheat spikes, while chlorophyll a/b ratio was increased, compared to high nitrogen level. Wheat variety also had a strong effect on chloroplast pigment content in wheat spikes. On average for all varieties, Ingenio and Isengrain

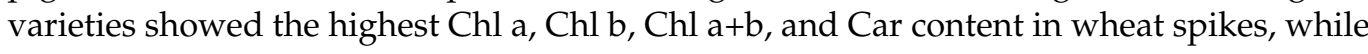
the lowest content of chloroplast pigments was in Bezostaya-1 variety (data not shown).

Observing the changes in chloroplast pigment content in each variety separately, Fusarium treatment, at both nitrogen levels, caused a decrease in Chl a, Chl b, and Car content in BC Mandica and Isengrain varieties (Figure 3a-c). In conditions of low nitrogen level, most non-inoculated varieties showed decrease in the content of chloroplast pigments compared to high nitrogen level. However, a significant decrease was found in Ingenio,

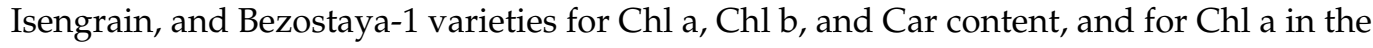
Galloper variety. 


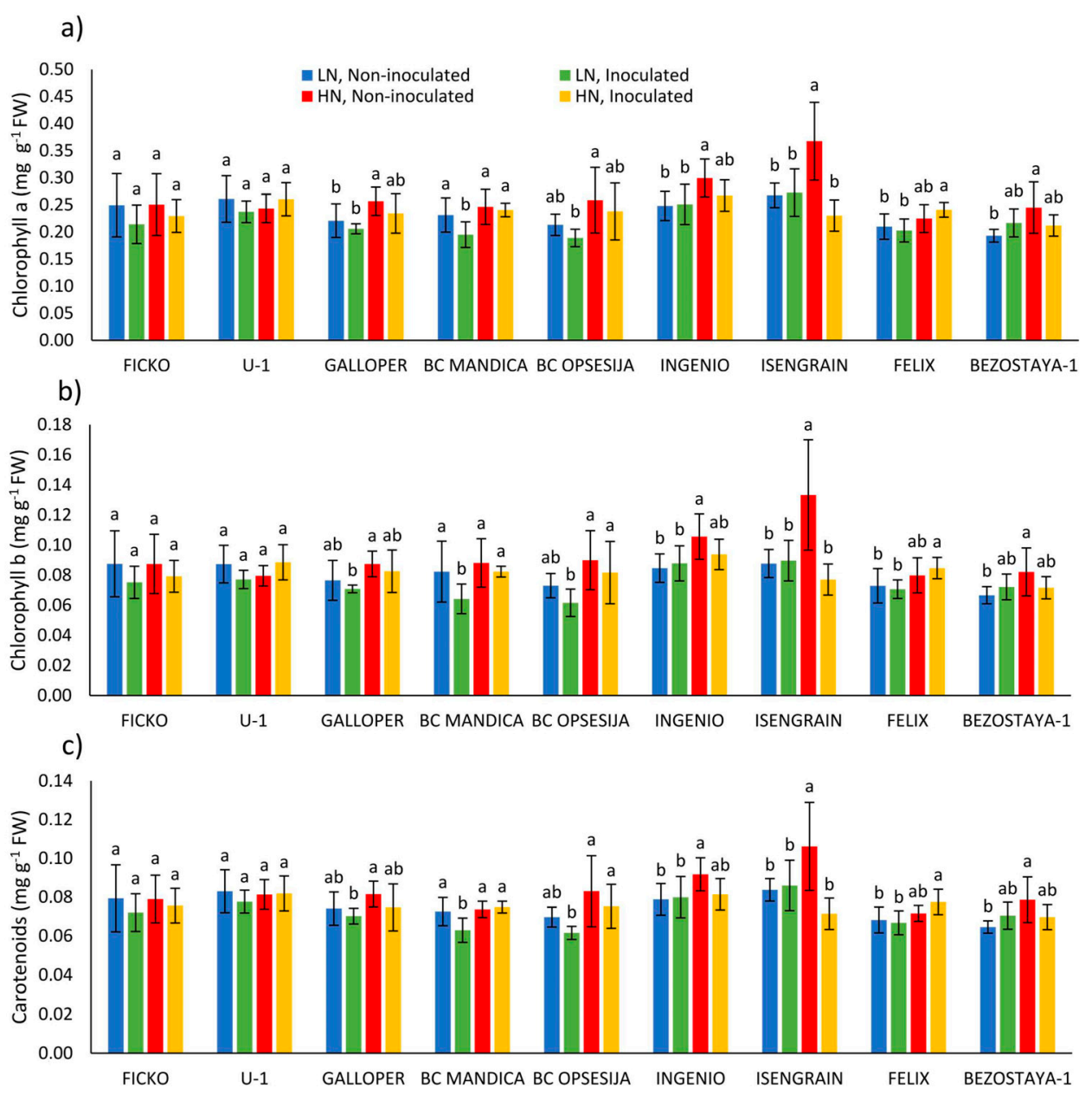

Figure 3. Chlorophyll a (a), chlorophyll b (b), and carotenoids (c) content in spikes of nine wheat varieties under different nitrogen (LN-low nitrogen; HN-high nitrogen) and Fusarium (noninoculated and inoculated) treatments. Values are means of six replicates \pm standard deviation (SD). Different letters above the bars indicate significant differences according to Fisher's LSD test $(p \leq 0.05)$ among different treatment in each variety separately.

\section{Discussion}

Both inadequate nitrogen fertilization and pathogen attacks can cause abiotic and biotic stress conditions in wheat production. To date, a scarce amount of studies are available on the influence of both FHB and different nitrogen fertilization on the oxidative and antioxidant response of wheat. In the present study, we examined the effect of nitrogen and Fusarium treatment on the occurrence of FHB and biochemical changes in spikes of nine wheat varieties in field conditions. In general, wheat variety, nitrogen, and Fusarium treatment had an impact on all tested parameters of oxidative stress and antioxidative response.

Considering different experimental conditions, various reports on the effect of nitrogen fertilization on FHB are available in the literature. According to some studies, high nitrogen levels increase disease incidence and intensity [16-18], whereas others reported restriction impact of nitrogen on Fusarium infection [19-21]. In the present study, in, Ficko, Galloper, and Felix varieties high nitrogen levels caused an increase in visual symptoms, compared to low nitrogen levels. Contrarily, in U-1 variety high nitrogen level caused a decrease in visual symptoms, suggesting a variety-specific response. However, to determine a more accurate effect of different nitrogen levels on FHB incidence and intensity, it is necessary to include testing at different nitrogen levels and more extensive mycological, and mycotoxin analyses. 
As an indicator of oxidative stress, lipid peroxidation can be a useful tool to evaluate cultivars' susceptibility to FHB [14]. However, in our study, we did not find any significant changes in the levels of lipid peroxidation caused by nitrogen or Fusarium treatment. Under the nitrogen deficiency and Fusarium treatment, increased lipid peroxidation was recorded only in Galloper variety, which could be explained by varietal susceptibility to Fusarium. On the other hand, in conditions of high nitrogen level, Fusarium treatment did not cause any significant changes in lipid peroxidation level. This could be explained by different plant responses to individual stress compared to a combination of stresses [22-24].

In conditions of low nitrogen level, Fusarium treatment considerably increased activities of some measured antioxidative enzymes (CAT, APX or GR) in most varieties. The exception was the Galloper variety, the only variety with increased lipid peroxidation level, where APX activity was decreased, indicating the importance of this enzyme in the defense response. Induction of enzymatic defense mechanisms is connected with FHBresistance, wherein more tolerant varieties activate the antioxidative enzymes faster and earlier in the infection process $[25,26]$. On the other hand, in conditions of high nitrogen levels, antioxidative enzyme activities were decreased in most infected wheat varieties. Although there were no changes in TBARS content, decreased activities of antioxidative enzymes could increase the incidence and intensity of FHB in conditions of high nitrogen levels. Different Fusarium impacts on antioxidative response in conditions of high and low nitrogen level could be due to different ROS formation and scavenging in conditions of single stress (Fusarium treatment) and combination of stresses (low nitrogen level and Fusarium treatment).

Polyphenols content, such as phenolic acids and flavonoids, increased under abiotic or biotic stress conditions, helping the plant to cope with environmental constraints [27,28]. In the present study, Fusarium treatment of wheat at low nitrogen level increased the phenolic content in BC Mandica variety, while in BC Opsesija variety phenolic content decreased in response to Fusarium treatment. Increased content of phenolics in BC Mandica variety could be a part of its defense response that could contribute against pathogen attack and spread. In conditions of high nitrogen level, Fusarium treatment of wheat decreased the phenolic content in Ficko, BC Mandica, Isengrain, and Bezostaya-1 varieties. When exposed to pathogen infection, plants often suffer significant chloroplast pigment loss [29]. In the present study, Fusarium treatment caused a decrease in all chloroplast pigments in BC Mandica and Isengrain varieties, in conditions of low and high nitrogen levels, respectively.

In this study, the most noticeable impact on the measured biochemical parameters in wheat spikes had a low nitrogen level itself. Various abiotic stress conditions lead to the overproduction of ROS and imbalanced ROS detoxification, which lead to lipid peroxidation $[8,30]$. The present study provided similar results, in which low nitrogen level as an abiotic stress factor caused an increase in lipid peroxidation in most varieties. Although a significant increase in lipid peroxidation was found only in non-inoculated Ficko and Bezostaya-1 varieties, which also showed reduced APX activities, indicating the importance of this enzyme in scavenging ROS. Moreover, in most varieties, low nitrogen level caused a decrease in antioxidant enzyme activities. Decreased activities of CAT, APX, and GR have also been demonstrated in other N-deficient plants [31,32]. The reduction in antioxidant enzymes activity could be connected with lower amino acid and protein synthesis in nitrogen deficiency conditions, compared to high nitrogen level conditions. In the present study, low nitrogen level caused a decrease in the soluble phenolic content in two varieties (BC Mandica and Isengrain). This finding is in contrast to other studies, in which the accumulation of phenolic components in plant tissues was enhanced under limited nitrogen conditions, due to increased C:N ratio within plants [33-35]. Although results were not shown in this study, phenolic contents were increased in flag leaves of most varieties, suggesting different tissue responses to nitrogen deficiency. Furthermore, low nitrogen level caused the reduction in chlorophyll a, chlorophyll b, total chlorophyll, and carotenoids content in wheat spikes in non-inoculated plants. Our findings are in accordance with previous studies in which decreased content of photosynthetic pigments 
under nitrogen-deficient conditions were found [3,36]. Low nitrogen level induces inhibition of photosynthesis and reduces photosynthetic capacity, which consequently inhibits plant growth and development [37,38].

The obtained results provided a better understanding on the biochemical aspects as a part of wheat defense mechanisms against necrotrophic fungi F. culmorum, under different nitrogen treatments. To our knowledge, this is the first report on the oxidative/antioxidative response of wheat to combined stress caused by Fusarium attack and different nitrogen levels. This research can serve as an additional tool in assessing wheat tolerance to various environmental stress conditions.

\section{Materials and Methods}

\subsection{Field Trial}

Field trial with nine winter wheat varieties of different origin (Table 4) was planted in 2017/18 season at location Osijek. The experiment was set-up in a split-split-plotfactorial design in three replicates with nitrogen fertilization levels as main plots, nine wheat cultivars as sub-plots, and Fusarium infection was applied at sub-sub-plot level.

Table 4. Winter wheat varieties and their origin.

\begin{tabular}{cccc}
\hline Variety & Country & Breeding Institution & Year of Release \\
\hline BC Mandica & Croatia & Bc Institut d.d. Zagreb & 2015 \\
BC Opsesija & Croatia & Bc Institut d.d. Zagreb & 2016 \\
Bezostaya-1 & Russia & Krasnodar Lukyanenko Research Institute & 1959 \\
Felix & Croatia & Agricultural Institute Osijek & 2007 \\
Ficko & Croatia & Agricultural Institute Osijek & 2007 \\
Galloper & Croatia & Agricultural Institute Osijek & 2014 \\
Ingenio & France & CC Benoist SA & 2010 \\
Isengrain & France & Florimond Desprez Veuve et Fils (FR) & 1997 \\
U-1 & Croatia & Agricultural Institute Osijek & 1936 \\
\hline
\end{tabular}

The soil type was eutric cambisol and the experimental plot size was $7.56 \mathrm{~m}^{2}$. Basic fertilization of $74 \mathrm{~kg} \mathrm{~N} \mathrm{ha}^{-1}, 80 \mathrm{~kg} \mathrm{P}_{2} \mathrm{O}_{5} \mathrm{ha}^{-1}$ and $120 \mathrm{~kg} \mathrm{~K}_{2} \mathrm{O} \mathrm{ha}^{-1}$ was applied by adding $100 \mathrm{~kg} \mathrm{ha}^{-1}$ of urea $(46 \% \mathrm{~N})$ and $400 \mathrm{~kg} \mathrm{ha}^{-1}$ NPK (7:20:30). The nitrogen treatment comprised of two nitrogen fertilization levels, $0 \mathrm{~kg} \mathrm{~N} \mathrm{ha}^{-1}$ (LN - low nitrogen) and $100 \mathrm{~kg} \mathrm{~N} \mathrm{ha}^{-1}$ (HN-high nitrogen), applied as top-dressings of $50 \mathrm{~kg} \mathrm{~N} \mathrm{ha}^{-1}$ at tillering (Zadok's scale 23-25) and stem extension (Zadok's scale 33-35) growth stages (Table 5). All other cultural practices including the application of herbicides, insecticides, and fungicides to control major weeds, insects and foliar diseases were typical for commercial wheat production in Croatia.

Table 5. Soil nitrogen $(\mathrm{N})$ content $\left(\mathrm{kg} \mathrm{ha}^{-1}\right)$ in Osijek in 2017/18 year.

\begin{tabular}{|c|c|c|c|c|c|c|c|c|}
\hline \multirow[t]{2}{*}{ Location } & \multirow[t]{2}{*}{ Soil Type } & \multirow[t]{2}{*}{ Season } & \multirow[t]{2}{*}{$\begin{array}{l}\text { Residual Soil N } \\
\quad\left(\operatorname{kg~N~ha~}^{-1}\right)\end{array}$} & \multirow[t]{2}{*}{$\begin{array}{c}\text { Basic N Fertilization } \\
\left(\mathbf{k g ~ N ~ h a} \mathbf{a}^{-1}\right)\end{array}$} & \multicolumn{2}{|c|}{$\begin{array}{l}\text { N Top-Dressing } \\
\left(\mathrm{kg} \mathrm{N} \mathrm{ha}^{-1}\right)\end{array}$} & \multicolumn{2}{|c|}{$\begin{array}{c}\text { Total N } \\
\left(\operatorname{kg~N~ha-1)~}^{-1}\right.\end{array}$} \\
\hline & & & & & $\mathrm{LN}$ & $\mathrm{HN}$ & LN & $\mathrm{HN}$ \\
\hline Osijek & $\begin{array}{c}\text { Eutric } \\
\text { cambisol }\end{array}$ & $2017 / 18$ & 20 & 74 & 0 & $50+50$ & 94 & 194 \\
\hline
\end{tabular}

\subsection{Inoculum Production, Inoculation Procedure, and Disease Evaluation}

Isolate F. culmorum obtained from the fungal culture collection of Faculty of Agrobiotechnical Sciences Osijek (Croatia) was used for inoculum production, according to the method of Snijders and Eeuwijk [39]. A mixture of wheat and oat grains (3:1, v/v) was soaked in water overnight. The following day, excess water was decanted and seeds were autoclaved and inoculated with F. culmorum isolate. Inoculated grains were incubated for three weeks at $25^{\circ} \mathrm{C}$, protected from sunlight. Macroconidia were washed 
off the colonized grains, and conidial suspension was diluted to a final concentration of $1 \times 10^{6}$ conidia $\mathrm{mL}^{-1}$. Only the first $\mathrm{m}^{2}$ of each subplot (variety) was inoculated, while the rest of the subplot was left to natural infection. Spray inoculations were carried out using a motor-driven backpack-sprayer in the late afternoon. Inoculations were performed individually on each subplot when $50 \%$ of the plants had reached anthesis (Zadok's scale 65 ) and repeated two days later. To maintain moisture for optimal infection conditions, plants were sprayed with water several times during the day. Visual scoring of the overall percentage of inoculated spikes showing FHB symptoms was performed 18 days after inoculation. The percentage of diseased spikes in each plot was determined on a linear scale $(0-100 \%)$ [40].

\subsection{Sample Preparation and Measurements}

Wheat spikes for measuring biomarkers of oxidative stress and antioxidant response were sampled 7 days after inoculation. Collected samples were immediately frozen in liquid nitrogen before being stored at $-80{ }^{\circ} \mathrm{C}$ prior to analysis. Wheat spikes were ground using a TissueLyser (Qiagen Retsch GmbH, Hannover, Germany) for 1 min at $30 \mathrm{~Hz}$. A fine powder obtained was weighed into microtubes for further analysis.

\subsection{Determination of Lipid Peroxidation Level}

The level of lipid peroxidation in wheat spikes was determined by measuring the concentration of reactive substances of thiobarbituric acid (TBARS), mainly malondialdehyde (MDA), according to the method of Verma and Dubey [41]. About $150 \mathrm{mg}$ of wheat spikes tissue was homogenized on ice with $1 \mathrm{~mL}$ of $0.1 \%(\mathrm{w} / \mathrm{v})$ solution of trichloroacetic acid (TCA) and centrifuged at $6000 \times g$ for $5 \mathrm{~min}$. To an aliquot $(0.5 \mathrm{~mL})$ of the supernatant, $1 \mathrm{~mL}$ of $0.5 \%$ thiobarbituric acid in $20 \%$ TCA was added, and the mixture was incubated in a water bath at $95^{\circ} \mathrm{C}$ for $30 \mathrm{~min}$. The produced red pigment was measured spectrophotometrically at $532 \mathrm{~nm}$ and $600 \mathrm{~nm}$. The absorbance at $600 \mathrm{~nm}$ is deducted from the absorbance at $532 \mathrm{~nm}$ due to the correction for a non-specific reaction. Results were expressed in $\mathrm{nmol}$ of TBARS per gram of fresh weight (nmol TBARS $\mathrm{g}^{-1} \mathrm{FW}$ ).

\subsection{Determination of the Soluble Phenolic Content}

Powdered wheat tissue was homogenized on ice with $1 \mathrm{~mL}$ of $80 \%$ ethanol $(1: 10, \mathrm{w} / \mathrm{v})$ and phenolic compounds were extracted for $24 \mathrm{~h}$ at $-20^{\circ} \mathrm{C}$. After extraction, samples were centrifuged at $21,000 \times \mathrm{g}$ at $4{ }^{\circ} \mathrm{C}$ for $15 \mathrm{~min}$ and supernatant was used for further measurements. Soluble phenolic content was determined by the Folin-Ciocalteu method [42]. The reaction mixture contained $20 \mu \mathrm{L}$ of sample, $1.58 \mathrm{~mL}$ of $\mathrm{H}_{2} \mathrm{O}, 100 \mu \mathrm{L}$ of Folin-Ciocalteu reagent, and $300 \mu \mathrm{L}$ of the saturated $\mathrm{Na}_{2} \mathrm{CO}_{3}$ solution. The reaction mixture was incubated in a water bath at $37^{\circ} \mathrm{C}$ for $60 \mathrm{~min}$, after which the absorbance was measured at $765 \mathrm{~nm}$. Soluble phenolic content was calculated from a standard curve using gallic acid as a standard and expressed as $\mu \mathrm{g}$ gallic acid equivalents (GAE) per $\mathrm{g}^{-1}$ fresh weight $\left(\mu \mathrm{g} \mathrm{GAE}{ }^{-1} \mathrm{FW}\right)$.

\subsection{Enzyme Activities}

A fine powder obtained after grinding was homogenized on ice in cold $100 \mathrm{mM}$ potassium phosphate buffer $(1: 5, \mathrm{w} / \mathrm{v})$ containing $1 \mathrm{mM}$ ethylenediaminetetraacetic acid (EDTA), and $0.2 \%(\mathrm{w} / \mathrm{v})$ polyvinylpyrrolidone (PVP), $\mathrm{pH}$ 7.0. The homogenized samples were then centrifuged at $21,000 \times \mathrm{g}$ at $4{ }^{\circ} \mathrm{C}$ for $15 \mathrm{~min}$, and the supernatants were used for the spectrophotometric determination of the activity of the enzymes catalase (CAT), ascorbate peroxidase (APX), and glutathione reductase (GR). Additionally, protein concentration in the enzyme extracts was determined using bovine serum albumin as a protein standard [43].

Briefly, catalase (CAT, EC 1.11.1.6) activity was measured according to Aebi [44]. The reaction mixture $(1.5 \mathrm{~mL})$ consisted of enzyme extract $(50 \mu \mathrm{L})$ and $0.036 \%$ in $50 \mathrm{mM}$ potassium phosphate buffer ( $\mathrm{pH}$ 7.0). The decrease in absorbance due to the oxidation of 
$\mathrm{H}_{2} \mathrm{O}_{2}$ was monitored at $240 \mathrm{~nm}$ over $2 \mathrm{~min}$. The CAT activity was calculated using a molar extinction coefficient $(\varepsilon=0.04 \mathrm{mM} / \mathrm{cm})$ and expressed in $\mathrm{U} \mathrm{mg}^{-1}$ protein.

Ascorbate peroxidase (APX, EC 1.11.1.11) activity was measured by an adjusted method from Nakano and Asada [45]. The reaction mixture $(1 \mathrm{~mL})$ consisted of enzyme extract $(50 \mu \mathrm{L}), 0.5 \mathrm{mM}$ ascorbic acid, $0.12 \mathrm{mM} \mathrm{H}_{2} \mathrm{O}_{2}$ and $0.1 \mathrm{mM}$ EDTA in $50 \mathrm{mM}$ potassium phosphate buffer ( $\mathrm{pH}$ 7.0). The decrease in absorbance due to the oxidation of ascorbate was monitored at $290 \mathrm{~nm}$ every $15 \mathrm{~s}$ for $3 \mathrm{~min}$. The APX activity was calculated using a molar extinction coefficient $(\varepsilon=2.8 \mathrm{mM} / \mathrm{cm})$ and expressed in $\mathrm{U} \mathrm{mg}^{-1}$ protein.

Glutathione reductase (GR, EC 1.6.4.2) activity was measured according to Halliwell and Foyer [46]. The reaction mixture $(1 \mathrm{~mL})$ consisted of protein extract $(50 \mu \mathrm{L}), 1 \mathrm{mM}$ oxidized glutathione (GSSG), $0.1 \mathrm{mM}$ reduced form of nicotinamide adenine dinucleotide phosphate (NADPH) and $1 \mathrm{mM}$ EDTA in $100 \mathrm{mM}$ potassium phosphate buffer (pH 7.5). A decrease in absorbance due to the oxidation of NADPH was monitored at $340 \mathrm{~nm}$ every $15 \mathrm{~s}$ for $2 \mathrm{~min}$. The GR activity was calculated using a molar extinction coefficient for $\operatorname{NADPH}(\varepsilon=6.220 \mathrm{mM} / \mathrm{cm})$ and expressed in $\mathrm{U} \mathrm{mg}^{-1}$ protein.

\subsection{Determination of Photosynthetic Pigment Concentration}

A fine powder obtained after grinding (about $100 \mathrm{mg}$ ) was homogenized on ice with the cold absolute acetone and reextracted until plant tissue was completely colorless. The samples were centrifuged at $21,000 \times g$ at $4{ }^{\circ} \mathrm{C}$ for $15 \mathrm{~min}$, and the supernatants were used for further measurements. The absorption of extracted photosynthetic pigments was measured at 470, 645 and, $662 \mathrm{~nm}$. Concentrations of photosynthetic pigments were calculated according to Lichtenthaler [47] and expressed as $\mathrm{mg} \mathrm{g}^{-1}$ fresh weight.

\subsection{Statistical Analysis}

All data analyses were performed using the SAS Enterprise Guide 7.1 (SAS Institute Inc., Cary, NC, USA) software. Assays were carried out in six replicates and their results were expressed as mean \pm standard deviation (SD). Factorial analysis of variance (ANOVA) was performed, and statistically significant differences among the treatments in each variety separately were determined using the Fisher's LSD test $(p \leq 0.05)$.

Author Contributions: Conceptualization, M.M., R.V., K.V., J.Ć., K.D. and D.N.; formal analysis, M.M., R.V. and D.N.; investigation, M.M., R.V., I.Š.Č., A.V., K.S., N.S. and D.N.; resources, R.V., K.V., I.S.C.. and D.N.; writing—original draft preparation, M.M.; writing—review and editing, R.V., K.V., I.Š.Č., J.Ć., A.V. and D.N.; visualization, M.M., R.V., K.V., I.Š.Č. and D.N.; funding acquisition, D.N. All authors have read and agreed to the published version of the manuscript.

Funding: This work was funded by the grant of the Croatian Science Foundation IP-2016-06-2178 and the EU project KK.01.1.1.01.0005 Biodiversity and Molecular Plant Breeding, Centre of Excellence for Biodiversity and Molecular Plant Breeding (CoE CroP-BioDiv), Zagreb, Croatia.

Institutional Review Board Statement: “Not applicable” for studies not involving humans or animals.

Informed Consent Statement: “Not applicable" for studies not involving humans.

Data Availability Statement: The dataset used and/or analyzed during the current study are available from the corresponding authors on reasonable request.

Conflicts of Interest: The authors declare no conflict of interest. The funders had no role in the design of the study; in the collection, analyses, or interpretation of data; in the writing of the manuscript, or in the decision to publish the results.

\section{References}

1. Duveiller, E.; Singh, R.P.; Nicol, J.M. The challenges of maintaining wheat productivity: Pests, diseases, and potential epidemics. Euphytica 2007, 157, 417-430. [CrossRef]

2. Tabak, M.; Lepiarczyk, A.; Filipek-Mazur, B.; Lisowska, A. Efficiency of Nitrogen Fertilization of Winter Wheat Depending on Sulfur Fertilization. Agronomy 2020, 10, 1304. [CrossRef] 
3. Liu, X.; Wang, S.; Deng, X.; Zhang, Z.; Yin, L. Comprehensive evaluation of physiological traits under nitrogen stress and participation of linolenic acid in nitrogen-deficiency response in wheat seedlings. BMC Plant Biol. 2020, 20, 501. [CrossRef] [PubMed]

4. Buerstmayr, M.; Steiner, B.; Buerstmayr, H. Breeding for Fusarium head blight resistance in wheat-Progress and challenges. Plant Breed. 2020, 139, 429-454. [CrossRef]

5. Savary, S.; Willocquet, L.; Pethybridge, S.J.; Esker, P.; McRoberts, N.; Nelson, A. The global burden of pathogens and pests on major food crops. Nat. Ecol. Evol. 2019, 3, 430-439. [CrossRef] [PubMed]

6. Ćosić, J.; Vrandečić, K.; Svitlica, B. Fusarium vrste izolirane s pšenice i kukuruza u istočnoj Hrvatskoj. Poljoprivreda 2004, 10, 5-8.

7. Cheeseman, J.M. Hydrogen peroxide and plant stress: A challenging relationship. Plant Stress 2007, 1, 4-15.

8. Hasanuzzaman, M.; Bhuyan, M.H.M.B.; Zulfiqar, F.; Raza, A.; Mohsin, S.M.; Mahmud, J.A.; Fujita, M.; Fotopoulos, V. Reactive Oxygen Species and Antioxidant Defense in Plants under Abiotic Stress: Revisiting the Crucial Role of a Universal Defense Regulator. Antioxidants 2020, 9, 681. [CrossRef]

9. Saddhe, A.A.; Malvankar, M.R.; Karle, S.B.; Kumar, K. Reactive nitrogen species: Paradigms of cellular signaling and regulation of salt stress in plants. Environ. Exp. Bot. 2019, 161, 86-97. [CrossRef]

10. Ahmad, P.; Tripathi, D.K.; Deshmukh, R.; Singh, V.P.; Corpas, F.J. Revisiting the role of ROS and RNS in plants under changing environment. Environ. Exp. Bot. 2019, 161,1-3. [CrossRef]

11. Groß, F.; Durner, J.; Gaupels, F. Nitric oxide, antioxidants and prooxidants in plant defence responses. Front. Plant Sci. 2013, 4, 419. [CrossRef] [PubMed]

12. Peterson, R.K.; Higley, L.G. Biotic Stress and Yield Loss, 1st ed.; CRC Press: Washington, DC, USA, 2000; p. 261. ISBN 0-8493-1145-4.

13. Španić, V.; Viljevac Vuletić, M.; Abičić, I.; Marček, T. Early response of wheat antioxidant system with special reference to Fusarium head blight stress. Plant Physiol. Biochem. 2017, 115, 34-43. [CrossRef] [PubMed]

14. Khaledi, N.; Taheri, P.; Falahati-Rastegar, M. Evaluation of resistance and the role of some defense responses in wheat cultivars to Fusarium head blight. J. Plant Prot. Res. 2018, 57, 205-217. [CrossRef]

15. Marček, T.; Viljevac Vuletić, M.; Bakula, I.; Alivojvodić, S.; Španić, V. Time-course experiment of Fusarium infestation of wheat genotypes with the emphasis on the physiological response. Croat. J. Food Sci. Technol. 2018, 10, 58-63. [CrossRef]

16. Lemmens, M.; Haim, K.; Lew, H.; Ruckenbauer, P. The effect of nitrogen fertilization on Fusarium head blight development and deoxynivalenol contamination in wheat. J. Phytopathol. 2004, 152, 1-8. [CrossRef]

17. Suproniene, S.; Mankeviciene, A.; Kadziene, G. The effect of different tillage-fertilization practices on the mycoflora of wheat grains. Agric. Food Sci. 2011, 20, 315-326. [CrossRef]

18. Vrandečić, K.; Jug, D.; Ćosić, J.; Ilić, J.; Jug, I. The impact of different conservation soil tillage and nitrogen fertilization on wheat grain infection with Fusarium sp. Poljoprivreda 2019, 25, 26-31. [CrossRef]

19. Yoshida, M.; Nakajima, T.; Tonooka, T. Effect of nitrogen application at anthesis on Fusarium head blight and mycotoxin accumulation in breadmaking wheat in the western part of Japan. J. Gen. Plant Pathol. 2008, 74, 355. [CrossRef]

20. Van der Burgt, G.J.H.M.; Timmermans, B.G.H.; Scholberg, J.M.S.; Osman, A.M. Fusarium head blight and deoxynivalenol contamination in wheat as affected by nitrogen fertilization. NJAS Wagening. J. Life Sci. 2011, 58, 123-129. [CrossRef]

21. Krnjaja, V.; Mandić, V.; Lević, J.; Stanković, S.; Petrović, T.; Vasić, T.; Obradović, A. Influence of N-fertilization on Fusarium head blight and mycotoxin levels in winter wheat. Crop. Prot. 2015, 67, 251-256. [CrossRef]

22. Jiang, Y.; Huang, B. Drought and heat stress injury to two cool-season turfgrasses in relation to antioxidant metabolism and lipid peroxidation. Crop. Sci. 2001, 41, 436-442. [CrossRef]

23. Rampino, P.; Mita, G.; Fasano, P.; Borrelli, G.M.; Aprile, A.; Dalessandro, G.; De Bellis, L.; Perrotta, C. Novel durum wheat genes up-regulated in response to a combination of heat and drought stress. Plant Physiol. Biochem. 2012, 56, 72-78. [CrossRef]

24. Haworth, M.; Marino, G.; Brunetti, C.; Killi, D.; De Carlo, A.; Centritto, M. The impact of heat stress and water deficit on the photosynthetic and stomatal physiology of olive (Olea europaea L.) -A case study of the 2017 heat wave. Plants 2018, 7, 76. [CrossRef]

25. Sorahinobar, M.; Niknam, V.; Ebrahimzadeh, H.; Soltanloo, H. Differential antioxidative responses of susceptible and resistant wheat cultivars against Fusarium head blight. Intl. J. Farm. Allied Sci. 2015, 4, 239-243.

26. Khaledi, N.; Taheri, P.; Falahati-Rastegar, M. Reactive oxygen species and antioxidant system responses in wheat cultivars during interaction with Fusarium species. Australasian Plant Pathol. 2016, 45, 653-670. [CrossRef]

27. Datta, J.; Lal, N. Temporal and spatial changes in phenolic compounds in response to Fusarium wilt in chickpea and pigeonpea. Cell. Mol. Biol. 2012, 58, 96-102. [CrossRef] [PubMed]

28. Sharma, A.; Shahzad, B.; Rehman, A.; Bhardwaj, R.; Landi, M.; Zheng, B. Response of phenylpropanoid pathway and the role of polyphenols in plants under abiotic stress. Molecules 2019, 24, 2452. [CrossRef]

29. Lobato, A.K.S.; Gonçalves-Vidigal, M.C.; Vidigal Filho, P.S.; Andrade, C.A.B.; Kvitschal, M.V.; Bonato, C.M. Relationships between leaf pigments and photosynthesis in common bean plants infected by anthracnose. N. Z. J. Crop. Hortic. Sci. 2010, 38, 29-37. [CrossRef]

30. Singh, P.; Jaiswal, S.; Sheokand, S.; Duhan, S. Morpho-physiological and oxidative responses of nitrogen and phosphorus deficiency in wheat (Triticum aestivum L.). Indian J. Agric. Res. 2018, 52. [CrossRef] 
31. Kandlbinder, A.; Finkemeier, I.; Wormuth, D.; Hanitzsch, M.; Dietz, K.J. The antioxidant status of photosynthesizing leaves under nutrient deficiency: Redox regulation, gene expression and antioxidant activity in Arabidopsis thaliana. Physiol. Plant 2004, 120, 63-73. [CrossRef]

32. Lin, Y.L.; Chao, Y.Y.; Huang, W.D.; Kao, C.H. Effect of nitrogen deficiency on antioxidant status and Cd toxicity in rice seedlings. Plant Growth Regul. 2011, 64, 263-273. [CrossRef]

33. Ibrahim, M.H.; Jaafar, H.Z.; Rahmat, A.; Rahman, Z.A. Effects of nitrogen fertilization on synthesis of primary and secondary metabolites in three varieties of kacip fatimah (Labisia pumila Blume). Int. J. Mol. Sci. 2011, 12, 5238-5254. [CrossRef]

34. Munene, R.; Changamu, E.; Korir, N.; Joseph, G.O. Effects of different nitrogen forms on growth, phenolics, flavonoids and antioxidant activity in amaranth species. Trop. Plant Res. 2017, 4, 81-89. [CrossRef]

35. Deng, B.; Li, Y.; Xu, D.; Ye, Q.; Liu, G. Nitrogen availability alters flavonoid accumulation in Cyclocarya paliurus via the effects on the internal carbon/nitrogen balance. Sci. Rep. 2019, 9, 2370. [CrossRef]

36. Laza, R.C.; Bergman, B.; Vergara, B.S. Cultivar differences in growth and chloroplast ultrastructure in rice as affected by nitrogen. J. Exp. Bot. 1993, 44, 1643-1648. [CrossRef]

37. Boussadia, O.; Steppe, K.; Zgallai, H.; El Hadj, S.B.; Braham, M.; Lemeur, R.; Van Labeke, M.C. Effects of nitrogen deficiency on leaf photosynthesis, carbohydrate status and biomass production in two olive cultivars 'Meski'and 'Koroneiki'. Sci. Hortic. 2010, 123, 336-342. [CrossRef]

38. Prinsi, B.; Negrini, N.; Morgutti, S.; Espen, L. Nitrogen Starvation and Nitrate or Ammonium Availability Differently Affect Phenolic Composition in Green and Purple Basil. Agronomy 2020, 10, 498. [CrossRef]

39. Snijders, C.H.A.; Van Eeuwijk, F.A. Genotype x strain interactions for resistance to Fusarium head blight caused by Fusarium culmorum in winter wheat. Theor. Appl. Genet. 1991, 81, 239-244. [CrossRef]

40. Anonymous. Foliar and ear diseases on cereals. EPPO Bull. 2012, 42, 419-425. [CrossRef]

41. Verma, S.; Dubey, R.S. Lead toxicity induces lipid peroxidation and alters the activities of antioxidant enzymes in growing rice plants. Plant Sci. 2003, 164, 645-655. [CrossRef]

42. Folin, O.; Ciocalteu, V. On tyrosine and tryptophane determinations in proteins. J. Biol. Chem. 1927, 73, 627-650. [CrossRef]

43. Bradford, M.M. A rapid and sensitive method for the quantitation of microgram quantities of protein utilizing the principle of protein-dye binding. Anal. Biochem. 1976, 72, 248-254. [CrossRef]

44. Aebi, H. Catalase in vitro. Methods Enzymol. 1984, 105, 121-126.

45. Nakano, Y.; Asada, K. Hydrogen peroxide is scavenged by ascorbate specific peroxidase in spinach chloroplasts. Plant Cell Physiol. 1981, 22, 867-880. [CrossRef]

46. Halliwell, B.; Foyer, C.H. Properties and physiological function of a glutathione reductase purified from spinach leaves by affinity chromatography. Planta 1978, 139, 9-17. [CrossRef] [PubMed]

47. Lichtenthaler, H.K. Chlorophylls and carotenoids: Pigments of photosynthetic biomembranes. Methods Enzymol. 1987, 148, 350-382. [CrossRef] 